\title{
European Formalism and Empiriocriticism: Formalism within the International Empiriocritical Movement
}

Serge Tchougounnikov

University of Burgundy Franche-Compté, Department of Arts, Dijon, France

Received: November 2019; Accepted: January 2020

\begin{abstract}
This paper argues that Russian Formalism is to be considered a constitutive part of the international empiriocritical movement-Ernst Mach (1838-1916) and Richard Avenarius's (1843-1896). The conceptual parallelism between Empiriocriticism and Formalism is striking indeed. Thus, the cornerstones of the empiriocritical approach-the concept of series [Reihe] and the concept of elements [Elemente], understood as sensations [Empfindungen]-are plainly recognizable within formalist theories: the notion of 'series' (for example, the notion of 'literary series' or 'poetic series', leading to the famous concept of 'literariness', literaturnost') and the very formalist idea of a necessarily perceptible character of aesthetic form are only two, most famous, examples of this astonishing affinity. Here are some of the most striking convergences between Empiriocriticism and Formalism: the relativity of any knowledge; continuity between knowledge and perception; the pragmatic dominant; the leitmotif of 'the Unsalvageable Ego'. Besides, the paper seeks to situate Russian Formalism within European Aesthetic German-speaking Formalism. This kind of formalism formulates some basic oppositions correlated to different types of forming being associated with specific means and specific formal devices to affect them. In this context, particular morphological features result in producing particular feelings conceived in the spatial or syntactic perspective. From its German-speaking analogue, Russian Formalism has inherited this relational and spatial definition of feelings and, largely speaking, of emotionality within art. Indeed, both formalisms treat emotion as a 'non-subjective', 'kinetic', 'syntactic' phenomenon located on the surface of aesthetic objects.
\end{abstract}

Keywords: Empiriocriticism, Russian Formalism, German-Austrian Formalism, Emotivity, Poetic language

\section{SOME CONCEPTUAL PARALLELISMS BETWEEN EMPIRIOCRITICISM AND FORMALISM}

Russian Formalism should be considered a constitutive part of the international empiriocritical movement. The importance of this theory for the Russian context is well known-suffice it to mention such names as Vladimir Lesevič (1837-1905), Nikolaj Valentinov (1879-1964), Georgij Plexanov (1856-1918), Aleksandr Bogdanov (1873-1928), Aleksandr Lunačarskij (1875-1933) or Vladimir Lenin (1870-1924) (cf. Steila 2013).

The conceptual orientation of the Russian Formalists expressed in the famous ostranenie theory is exactly empiriocritical. Surely, the Russian Formalist manoeuvre has already been defined as positivist, but in this case it deals with a very particular kind of positivism, that of the second generation, the first one having been that of August Compte (1798-1857). Indeed, according to Shklovsky 'the purpose of art is to impart the sensation of things as they are perceived and not as they are known', whereas 'the process of perception is an aesthetic end in itself and must be prolonged' (quoted in: Richter 1998, 721, 741). The extraordinary success of the formalist concept of ostranenie ('defamiliarization') comes from the fact that it is based on the confusion of two concepts thoroughly distinguished within the scientific psychology at the turn of the 20th century: sensation [oščuščenie] and feeling [čuvstvo]. One remembers that the already-too-famous principle of ostranenie is rooted in the form's perceptibility 
and aims to increase the difficulty and length of sensation. The concept of ostranenie reveals formative potential in the elementary fact of sensation.

Within the scientific psychology at the turn of the $20^{\text {th }}$ century, the notion of feeling or sense [Gefüh/] is clearly differentiated from the notion of sensation [Empfingung], and the term 'sensation' is systematically opposed to those of 'feeling' or 'sense'. The only exception is the 'empiriocritical' approach: Ernst Mach (1838-1916) and Richard Avenarius's (1843-1896) Empiriocriticism (Eisler 1922, 281). Indeed, for both of these theorists, feelings are effects of organic sensations and of corporeal excitements, and feelings [Gefühle] are fused with organic sensations [Empfindungen] and with sensations of tensions (Mach 1886, 16; Avenarius 2008[1905], 53-54).

E. Mach designates sensations as elements [Elemente] and perceives them as the constituents of things themselves. For Mach, 'Bodies do not produce sensations, but complexes of sensations (complexes of elements) make up bodies' (Mach 1897, 22). Mach's student Joseph Petzoldt (1862-1929) considers all 'elements' as sensations, to the extent that they depend on our organism. For him, things do not generate sensations-it is 'complexes of elements' that constitute things (Eisler 1922, 281). For Avenarius, sensations are the 'elements of reality', insofar as they depend on the system of the organism. Avenarius's programme associates feelings with their physiological or organic substratum-with muscular or other organic sensations, reducing basic feelings (pleasure/displeasure) to their biological foundations (Avenarius 2008[1905], 53-54). Thus, the Formalist position reveals itself as a purely empiriocritical one: both of these movements associate sensations with feelings; for both of them, to feel and to perceive is the same thing.

The most polemical aspect of Empiriocriticism is its definition of the subject; this is also the feature that distinguishes it more from traditional psychological approaches. Indeed, according to the empathy-orientated position, the self is a focal and irreducible thing, as a qualitative mental reality. For Empiriocriticism, the subject, on the contrary, is nothing but a connection of anonymous psychic 'series'; this point of view leads to the dissolving of the self in such anonymous perceptible elements. Mach writes:
'But if we take the ego simply as a practical unity, put together for purposes of provisional survey, or simply as a more strongly coherent group of elements, less strongly connected with other groups of this kind, questions like those above discussed will not arise and research will have an unobstructed future' (Mach 1897, 22).

One recognises immediately the favourite topic of the Russian Formalists.

The conceptual parallelism between Empiriocriticism and Formalism is striking indeed. Thus, the cornerstones of the empiriocritical approach-the concept of series [Reihe] ${ }^{1}$ and the concept of elements [Elemente], understood as sensations [Empfindungen] ${ }^{2}$-are plainly recognisable within formalist theories: the notion of 'series' (for example, the notion of 'literary series' or 'poetic series', leading to the famous concept of literariness, literaturnost') and the very formalist idea of a necessarily perceptible character of aesthetic form are only two, most famous, examples of this astonishing affinity.

Here are some of the most striking convergences between Empiriocriticism and Formalism.

\section{THE RELATIVITY OF ANY KNOWLEDGE}

As Empiriocriticism, Formalism emphasises the relativity of any knowledge. According to Mach, 'Thing, body, matter, are nothing apart from their complexes of colors, sounds, and so forth-nothing apart from their so-called attributes (...)' (Mach 1897, 6). Both are in the position of bracketing absolute ontological proofs and personal subjectivity; this position is very clearly expressed in Mach's Analysis of the Sensations. ${ }^{3}$

\section{Mach writes:}

As soon as we have perceived that the supposed unities "body" and "ego" are only makeshifts, designed for provisional survey and for certain practical ends (...), we find ourselves obliged (...) to abandon them as insufficient and inappropriate. The antithesis of ego and world, sensation (phenomenon) and thing, then vanishes, and we have simply to deal with the connexion of the elements (...) (Mach 1897, 6).

Mach's particular empiricism is close to the formalist point of view, from the standpoint of what can be defined as critical epistemology and 'cultural relativity' (cf. Arens 1989, 218-220).

1 One finds in Avenarius different modifications of his very frequent concept of 'series': 'vital series' (Vitalreihe); 'psychic series' (psychische Reihen); 'purely affective series' [rein affektive Reihen]; 'purely appetitive series' [rein appetitive Reihen] (Avenarius 1907, 17-19, 79, 150, 166, 193; Avenarius 1908, 3, 214, 220, 266, 302, 383-384). See also J. Petzoldt's comments on this concept in: Petzoldt (1900, 92-112, 126-129). See also: Avenarius 2008(1905), 24-48.

2 Avenarius defines 'element' [Element] and 'character' [Charakter] as two classes of 'psychic images' or 'essential images' [psychische Gebilde or Grundgebilde]; for frequent use of these concepts see: Avenarius (1907, 15-16); and Avenarius (1908, 363-364). See also J. Petzoldt's comments on this concept in: Petzoldt (1900, 112-115). See also: Avenarius 2008(1905), 48-52.

3 According to K. Arens, Mach (who is justly acknowledged as a major source for Einstein's concept of special relativity) 'was in the position of bracketing both absolute ontological proofs and personal subjectivity'

(Arens 1989, 219). 
Both 'critics of experience'-Mach's system and formalist theory-are characterised by an empiricist, 'naïve' point of view. Similarly, both methods seek to dislodge the observer from a fixed position in the observed data.

\section{CONTINUITY BETWEEN KNOWLEDGE \\ AND PERCEPTION}

Another convergence is the emphasis both movements put on the relationships between knowledge and perception.

Mach's theory of elements exposed in his Analysis of the Sensations seeks to formulate a general epistemological principle, according to which any science begins with an analysis of sensations (cf. Arens 1989, 223). Both Empiriocriticism and Formalism try to reduce the field of sciences to the set of 'elements of sensations' connecting the outer physical dimension (colours, tones, and movements) with the inner dimension (psychological facts such as moods, feelings, and volition).

'Thus, perceptions, ideas, volition, and emotion, in short the whole inner and outer world, are composed of a small number of homogeneous elements connected in relations of varying evanescence or permanence. Usually, these elements are called sensations (...)' (Mach 1897, 18).

Both seek to extract from what appears to be solid and distinct bodies a set of stable and persistent complexes called 'elements of sensation': 'gradually, different complexes are found to be made up of common elements. The visible, the audible, the tangible, are separated from bodies. The visible is analysed into colours and into form. In the manifoldness of the colours, again, though here fewer in number, other component parts are discerned such as the primary colours, and so forth. The complexes are disintegrated into elements' (Mach 1897, 5).

\section{THE PRAGMATIC DOMINANT}

Both research programmes are pragmatically orientated, for they aim at a formalisation of any scientific discipline. Thus, Mach tries to define basic mental mechanisms (such as continuity or consistency) that 'treat data in predictable patterns based on pragmatic unities of perceived data' (Arens 1989, 226). In this sense, the formalist manoeuvre is highly 'empiriocritical': under the name of 'device', it lays bare the mental strategies that underlie scientific formalisations for the science of literature and of language in general. Both of these manoeuvres imply, consequently, the redefinition of systematic knowledge. Methodologically, this point leads to the identification between the mental and the physical with respect to the above-mentioned 'elements'. Mach writes:

'Colours, sounds, temperatures, pressures, spaces, times, and so forth, are connected with one another in manifold ways, and with them are associated moods of mind, feelings and volitions (...). Relatively greater permanency exhibit, first, certain complexes of colours, sounds, pressures, and so forth, connected in time and space, which therefore receive special names, and are designated bodies. Absolutely permanent such complexes are not' (Mach 1897, 2)

The Formalist science, as well as the empiriocritical programme, is a study of the dependencies among certain classes of 'elements of experience', contributing to create a new kind of scientific discourse (cf. Arens 1989, 230). For both Mach and the Formalists, the 'scientific truth' is a product of mental mechanisms that are seIf-restricting and relative to the field of data to be considered in the context of a particular experience. Both projects are seeking a different definition of science; they deal with the ideal of science conceived as a production of models that correspond not to the so-called 'reality' but only to a system of perceptions constituted for a particular purpose (cf. Arens 1989, 222-223).

\section{THE LEITMOTIF OF 'THE UNSALVAGEABLE EGO'}

In both of these movements, the relative stability of the stream of sensations replaces the consistency of the personal ego or of subjective existence. For Mach, 'The ego is unsavable' (Mach 1897, 20). 'The ego is not a definite, unalterable, sharply-bounded unity. None of these attributes are important, for all vary even within the sphere of individual life, in fact their alteration is even sought after by the individual. Continuity alone is important' (Mach 1897, 20).

It deals with an essentially formalist theme. Russian Formalism shares this orientation not only with the empiriocritical programme but also with other thinkers of the fin de siècle, such as Hermann Bahr, Fritz Mauthner and those from the Vienna Circle (cf. Arens 1989, 240). Following Mach's epistemology, Hermann Bahr, the Austrian journalist and essayist, formulates in his essay 'The Unsalvageable Ego' (1904), the idea that the personal ego has a purely heuristic value. This statement reflects a kind of cultural pessimism of the turn of the century (Arens 1989, 222). Mach writes: 'As relatively permanent, is exhibited, further, that complex of memories, moods, and feelings, joined to a particular body (the human body), which is denominated the "I" or "Ego" (...) Of course, the ego also is only of relative permanency' (Mach 1897, 3).

Mach's psychology is an interaction between objective and subjective spheres, between the 'perceiving consciousness' and the elements composing reality. It is in the same sense that the Formalists speak about 'literariness' and 'poeticality' as the only given reality of formal study. The same attitude is characteristic of the relationship between subjectivity and objectivity. In the empiriocritical sense, the Formalists try to define the perceiving ego as a matter of habit, as a construction. In both cases-Mach and the Formal circle-ego is nothing but a construct based on the relative stability of the stream of sensations: a system of elements precedes the perceiving consciousness. From this point of view, 'The primary fact is not the I, the ego, but the elements (sensations). The elements constitute the l' (Mach 1897, 19). In such a way, 'The Unsalvageable Ego' means that 
the radical relativity extended to personal consciousness has become a leitmotif and an essential message of Formalist theories.

If we turn to specific quotations, it will be easy to see some concrete examples of the convergences between the two approaches. Thus, one finds within Formalism numerous reverberations of the empiriocritical concept of 'element'. Indeed, in Formalism this 'element'-like perceptible principle is constitutive of any aesthetic object.

Like any empirical object of Mach's epistemology, the Formalist aesthetic object is defined through its 'perceptive' qualities. In both cases, it deals with some concrete constellation of perceptive values that are intrinsically extracted by the perceiving subject: 'For us, colours, sounds, spaces, times, are the ultimate elements, whose given connexion it is our business to investigate' (Mach 1897, 23).

Indeed, the oscillating mood of relationships between the 'constructive factor' and 'material', as formulated within Formalism, is purely sensitive: the relationship between both of these factors corresponds to the definition of Mach's 'element'. This principle establishes the Formalist model of 'literary evolution' (Tynyanov), in which the elements of data are necessarily perceived at the background of the previous (automatized) literary tradition. The same perceptual mechanism explains Shklovsky's law of 'the canonisation of the junior branch', with its evolutionary role of peripheral elements (also called 'sub-literary' or 'inferior' genres). Tynyanov's concept of 'innovating archaists' also forms an 'element'-like mechanism, allowing the analysis of sensations or the evolution of data within the literary field. Another example would be the Formalist relativist concept of the 'literary fact' (Tynyanov): from the Formalist standpoint, the consciousness of systematic evolution manifests itself as a fusion of feeling and sensation. In this respect, it is rather analogous to Mach's introspective analysis of sensations.

The 'laying bare of the device', the 'naked' verbal play, which Shklovsky discovers in Sterne and many other authors, is another example of the empiriocritical element. Thus, the distinction between Sterne's experimental novel and any conventional novel is also of sensual nature. In the case of Sterne, this 'element'-like mechanism manifests itself through a series of purely perceptible factors: long digressions, textual omissions and free transposition of textual fragments.

The famous Formalist concept of the dominant, defined as the pre-eminent component or group of components, also allows of an empiriocritical interpretation. The dominant makes it possible to analyse a series of perceptual units or a set of sensation-related complexes. One more example of this 'element'-like mechanism would be a 'verbal gesture' from Eikhenbaum's analysis of Gogol's The Overcoat (1919) or Tynyanov's analysis of poetic semantics in his the Problem of Verse Language (1924).

The leitmotif of the empiriocritical dissolution of the ego can be illustrated with the Formalist idea of the literary hero, according to which the latter is conceived of as a simple result of the needs of literary technique. Suffice it to quote Shklovsky's analysis of Cervantes's novel ('How Don Quixote Was Made', 1929) aiming to explain the composite and psychologically strange portrait of Cervantes's knight. The technique of Cervantes's novel combines fragmented discursive pieces; his hero eventually appears as an accidental result, or a collateral effect, of this technical integration of initially heterogeneous units. One will find more examples in Shklovsky's definition of the second part of Don Quixote as a 'loose mosaic of anecdotes' slowing down the action or when he speaks of The Decameron's interpolated short stories [vstavnye novelly]. Thus, the paradoxical psychology of literary heroes (for example, Don Quixote's contradictory psychological features combining madness with wisdom) results from mere technical expedience and can also be considered as a by-product in the empiriocritical sense.

One can also quote Shklovsky's idea of 'art as device' and his concrete models of 'the stepped structures' [stupenčatoe postroenie], which largely belong to the same optics. That is why the literary hero is merely a 'thread' on which heterogeneous episodes are 'strung' [nanizany] or a pretext for the unfolding of the action. In his Theory of Prose, Shklovsky applies the same model to the analyses of an adventure story (like The Odyssey, Sindbad or Lessage's Gil Blas and the Spanish novel Lazarillo de Tormes). The hero is a pretext for 'stringing up' [nanizyvanie] and 'framing' [obramlenie] of a series of quasi-independent stories (one finds detailed résumés of these Formalist positions in Erlich (1951, 241-245) and Aucouturier (1994, 34-40).

According to this syntactic definition, the literary hero is merely the by-product of the narrative structure and a compositional rather than a psychological entity as such. This vision is a literal application of the empiriocritical model of this symptomatic dissolution of the personal ego, postulated in Mach's analysis of sensations.

\section{THE RELATIONAL DEFINITION OF THE AESTHETIC OBJECT}

Russian Formalism belongs to the mainstream of the European psychological aesthetics of the turn of the 20th century. The latter is formed within the Herbartian movement and leads to the emergence of the German-speaking formalist aesthetics. The pioneering study of Karl Clausberg of 1983 puts forward a direct relationship between, on the one hand, Russian and Czech formalism and structuralism and, on the other hand, the Austrian aesthetic formalism (Alois Riegl's Vienna School). The merit of this study consists in indicating clearly the common substrate of both formalist approaches: Johannes Herbart's psychology and psychological aesthetics (Clausberg 1983, 55-76; see also: Clausberg 2011, 21-76). In 1997, Lambert Wiesing established a correlation between German formalism and Russian formalism (with reference to B. Ejxenbaum, V. Shklovsky, J. Tynyanov). Wiesing formulates the same idea as Clausberg: 
according to Wiesing, both these formalisms share the same psychological substratum, those of Herbartian psychological and relationist aesthetics. Both formalisms converge also in the 'neo-Kantian' perspective: to show it, Wiesing refers to Ejxenbaum's developments in 'The theory of the formal method' (1925) where the formalist approach is posed as an analysis of 'form understood as background in itself'. Indeed, Ejxenbaum opposes his 'form as background' to any dualism (form-symbol) of symbolist theories in which 'something fundamental necessarily transpires through form' (Ibid., 166).

These formalisms meet in the relational, or purely formal, definition of the aesthetic object ${ }^{4}$.

Thus, Herbart writes that 'any aesthetic judgement concerns relationships and never concerns something which could be defined as a simple matter' (quoted in: Wiesing 2014[1997], 60). From the Herbartian perspective, what is decisive from the aesthetic point of view is found 'in inner relationships between forms' (quoted in: Wiesing 2014 [1997], 59).

This syntactic orientation in the analyses of feeling continues in the formalist aesthetic of Herbart's disciples such as the Austrian-Czech musicologist Eduard Hanslick (1825-1904) and philosopher Robert Zimmermann (1824-1898).

Hanslick, in his 1854 study of beauty in music (Vom Musikalisch-Schönen: Ein Beitrag zur Revision der Ästhetik der Tonkunst), gives a classical example of this approach. According to Hanslick, sound figures in music are purely dynamic formations; the only principle of their organisation comes from their dynamics. Thus, music does not represent the content of feelings (sadness, joy, fear, etc.), but only their dynamic aspects. Music can imitate the movement of the psychic process only from the standpoint of its rapidity or slowness, or also from the point of view of its force or weakness, its going up or its going down (Hanslick 1982 [1854], 34). For Hanslick, music can grasp only movement: movement constitutes the only communicative element between music and human emotive states. Movement is a dynamic substratum that can receive any variable content according to different states of every individual consciousness (ibid., 35).

R. Zimmermann's programme of general aesthetics as a science of form (Allgemeine Ästhetik als Formwissenschaft, 1865) leads to the idea of form as an aesthetic relationship (quoted in: Wiesing 2014[1997], 59). The aesthetic object is defined as a 'simple set' or a 'simple complex' of 'objective forms' that 'eliminate the objective quid (what) belonging to the members of this complex as a theoretically unknowable and aesthetically indifferent matter' (quoted in: ibid., 61). For Zimmermann, 'Herbartian aesthetics can be only purely formal: the objects of aesthetical judgement are but relationships, forms' (ibid., 61).

Starting with Herbart's relational redefinition of feelings and the formalisation of the aesthetical object in the works of Herbartians, the formal approach in German-speaking aesthetics has elaborated various modifications of this initial point of view.

\section{RUSSIAN FORMALISM WITHIN EUROPEAN AESTHETIC FORMALISM}

Alois Riegl (1858-1905), an Austrian historian of art, redefined, in his writings published in Vienna around 1900, the notion of 'feeling' (and that of 'emotion'), as well as the general problematics of emotionality in art, through his famous distinction of the two modes of sensual experience: the tactile (or haptic) and the optic forms ${ }^{5}$ (Riegl 2014[1901], 80-85; 143-144).

Indeed, these two modes of sensual experience of the two types of style are intimately connected with the representation of feelings and emotions. The distinction has to do with a profound mechanism of emotional genesis and representation. The tactile or haptic style is radically anti-emotional because it thoroughly avoids any deep space: it merely seeks to represent the object. This goal is not compatible with any illusion of depth. Among artistic devices, the illusion of deep space is created through a system of foreshortenings and shadows. According to Riegl, foreshortenings and shadows as betrayers of deep space are associated with a manifestation of emotions that reveal the subjective life of the soul. Conversely, the growth of optical perspective designates the growth of subjective life and, consequently, the role of personal emotions (Riegl 2014[1901], 127-132).

Moving from one basic style to another is of psychological nature (Riegl 2014[1901], 143-144, 153, 225-233). This idea is especially clearly formulated in his article 'Mood as the Subject Matter of Modern Art' (Die Stimmung als Inhalt der modrnen Kunst, 1899).

\footnotetext{
4 This genealogy of the Russian Formalism is actually well attested. After Hansen-Löve (1978) and Clausberg's (1983) pioneering insights, the profound conceptual continuity between German-speaking Formalism and Russian Formalism was recently confirmed in a series of studies (cf. Wiesing 2014 [1997]; Maigné 2007, 170-177; Maigné 2009, 55-76; Maigné 2012; Tchougounnikov 2009, 231-248; Romand, Tchougounnikov 2010, 521-546; Tchougounnikov 2014, 141-147; Tchougounnikov 2016a, 353-357; Tchougounnikov 2017, 103-114). More generally on the Herbartian genealogy of the Russian Formalism see also Sirotkina (2004), Svetlikova (2005); Romand and Tchougounnikov (2008, 223-236); Romand and Tchougounnikov (2009), Clausberg (2011, 21-76); and Romand and Tchougounnikov (2013, 83-121).

5 He did in his study Late Roman Arts and Crafts [Die spätrömische Kunstindustrie nach den Funden in ÖsterreichUngarn] (Riegl 2014[1901]). One will find another example of syntactic or relational approach to feeling in his study The Group Portrait in Dutch Art [Das holländische Gruppenportrait] (Riegl 2008[1902]).
} 
The stylistic shift from the haptic to the optic is conditioned for Riegl by the inner psychological factor he calls 'the drive for harmony'. According to Riegl, the person has an emotional need for harmony, and strives to experience a redeeming mood of harmony. That is why one gradually abandons the tactile style connected to the condition of 'permanent unrest'. An optic style lets the person express the desired world harmony not found in nature. In this way, people realise their inner trend to free themselves from a feeling of unease. According to Riegl, 'the modern need for Stimmung can be satisfied only by a distant vision painting based on purely optical perception' (cf. Barasch 1990, 156-159).

Thus, the drive to a particular mood [Stimmung], that of 'redeeming harmony', requires some morphological or stylistic characteristics embodied in the optic style (or in distant vision). The 'redeeming quality of resolving dissonances' is a mere emotional effect of visual (optic) perceiving modality. ${ }^{6}$

Like Riegl, Adolf Hildebrand (1847-1927), German sculptor and theoretician of form, advances the idea of dissolving emotional charge or emotionality of art, in contrast to the double modality of seeing: Nahbild (close image) and Fernbild (distant image). The first kind of seeing is seeing like touching [abtasten] the object while the second kind of seeing is purely visual [Gesichtsvorstellung] (Hildebrand 1913[1893], 5-10).

According to Hildebrand, the emotion is dissolved in the organisation of planar compositions. The deep space is associated with troubling character, for it immerses the spectator in the chaotic unknown. On the contrary, the planar composition is pleasing because of its harmonious and well-balanced arrangement. Thus, the spatial relationship of figures and other representations acquires emotion-like qualities and appears as an equivalent of emotions acting on the potential emotive attitude of the spectator. Hildebrand's approach seeks to introduce a system of relational feelings into the very construction of the aesthetic object. The division of picture space into strata or planes, the stratification into planar layers, is conceived as an emotion-producing activity. Its object is a relationally based emotionality of the work of art. Thus, the artistic emotionality is integrated into the spatial organisation of the object (Hildebrand 1913 [1893], 57-75).

The formalisation of feelings continues in the later traditions of German-speaking aesthetics, and especially in the works of Heinrich Wölfflin (1864-1945) and Wilhelm Worringer (1881-1965).

Wölfflin's typology of basic forms in pictorial art is organised around the dichotomy 'linear style-pictorial style', where the first one is space-eliminating and an emotion-neutralising presentation, while the second is space-producing and an instance of emotion-generating formation (Wölfflin 1983[1915]).
Worringer defines two attitudes or two basic assumptions taking place in the mind of the spectator looking at the work of art: empathy and 'drive to abstraction'. Both attitudes possess representational or morphological correlations; the attitude called 'empathy', understood as a natural intuitive ability to participate in the emotions of others, is orientated towards lines evoking living natural forms; its functioning is based on the reproduction of emotions and on emotional participation. The attitude called 'drive to abstraction' consists in avoiding any emotions; it correlates to the geometrical or symmetrical pattern. Worringer's opposition refers to precise kinds of feeling having as psychological equivalents, firstly a 'happy' relationship of confidence between the person and the external world (like classical Greek art) and, secondly, the outcome of a great inner unrest inspired by the phenomena of the outside world (like arts of the Islamic world) (Worringer 1981 [1907]).

Thus, German-speaking formalism formulates some basic oppositions correlated to different types of forming being associated with specific means and specific formal devices to affect them. In this context, particular morphological features result in producing particular feelings conceived in the spatial or syntactic perspective.

\section{THE EMOTIONALITY OF ART ACCORDING TO TYNYANOV}

From its German-speaking analogue, Russian Formalism has inherited this relational and spatial definition of feelings and, largely speaking, of emotionality within art. The case of Yuri Tynyanov's (1894-1943) definition of emotion clearly illustrates this fact.

For Tynyanov, the construction of poetic language is oriented towards the maximal emotional effect. Within this emotional orientation, the secondary so-called 'hesitating' semantic features (which Tynyanov opposes to basic semantic features of lexical units) are especially important (Tynyanov 2002 [1924], 71-76).

In this context, Tynyanov's important references are psychologists Wilhelm Wundt (1830-1920) and his disciple Alfred Rosenstein. Tynyanov gives many quotations from A. Rosenstein's treaties The Psychological Meaning of the Change of Meaning [Die psychologische Bedeutung des Bedeutungswechsel der Wörter, Danzig, 1884]. For Rosenstein, verse is an 'emotive system'. This emotive nature of verse conditions its semantic system. Verbal meanings are conditioned not only semantically through notions, but also through emotions. Rosenstein connects to this psychological fact the effects of lyric poetry. Certain emotive states [Stimmungen] of readers make them predisposed to follow some movements of their feelings rather than the movements of their representations. According to Rosenstein, it is possible to explain a semantic element

6 On the opposition between 'close vision' [Nahsicht], normal vision [Normalsicht] and distant vision [Fernsicht] see Riegl (2014[1901], 145-147). 
from the point of view of its emotive role (Tynyanov 2002[1924], 103-104).

When there are several words for the only representation, the poet would choose among them the most emotionally charged word: for the representation of 'horse' he would choose Ross instead of Pferd; for that of 'forest', Hain instead of Wald; for that of 'ship', Nachen instead of Kahn; for 'money', Gold instead of Geld; for 'old man', Greis instead of alter Mann. Thus, the poet would prefer noble poetic terms to banal and everyday, albeit more exact, words because of their larger emotional charge, resulting exactly from their lack of precision (Tynyanov 2002 [1924], 144).

Tynyanov does not agree with Rosenstein's 'large definition' of poetic semantics; that is why, in order to 'reduce' it, he refers to W. Wundt's definition of 'emotion'. Tynyanov quotes a fragment from Wundt's Principles of Physiological Psychology (Grundzüge der physiologischen Psychologie, 1900), where emotion receives a somewhat relational definition.

For Wundt, 'the emotions directly associated with aesthetic objects are determined in their specific properties through the relationship that connects the parts of a given representation. This relationship is something objective, independent from a particular way in which impressions affect us; from this fact, it largely contributes to move apart subjective general feelings characteristic for any aesthetic impact' (quoted in: ibid., 105).

What seems to attract Tynyanov in Wundt's definition is the idea of a non-subjective, or objective, emotion. It deals with an emotion taken in its structural or compositional dimension; it means as a syntactic phenomenon. Tynyanov retains in this definition its structural or composition aspect, the fact that the emotion is assimilated to reciprocal disposition of parts or constituents of the 'verbal representation'. Viewed in this way, the emotion appears as an equivalent of the composition of the artistic work. As a phenomenon connected to composition, emotion implies some structuring and organisational order.

Thus, for Tynyanov, the composition of the artistic work dictates the emotive order and determinates its effect. In the psychology of this period-including Wundt's psychological theory-emotion is a complementary mental element of any representation. Emotion possesses sensation as the physiological base. The syntax of emotions would be an equivalent of differences between emotional effects connected to different sensations (Romand, Tchougounnikov 2010, 528-529).

From Tynyanov's perspective, the notion of artistic emotion leads to the question of relationships between the constituents of a 'verbal representation'. This kind of relationship builds an equivalent to the relationships between constituents of an artistic work. The difference between two of these relationships is formulated by Tynyanov as an opposition between 'simple emotions' connected to words and 'artistic emotions', which are defined as 'composite' or 'complex'. Within poetic texts, 'simple emotive associations' are repressed through 'artistic emotions' (Tynyanov 2002 [1924], 105).

The following conclusion can be made: coming from Wundt's definition of emotion, Tynyanov replaces the idea of a 'simple emotion' with the idea of 'the objective correlation between the parts of representation' [ob'ektivnoe sootnošenie častej predstavlenija]. This 'objective correlation' is determined by the construction of an artistic work [konstrukcija xudožestvennogo proizvedenija]. As a result of this syntactic or relational reformulation of emotion realised by Tynyanov, one sees disappearing (to borrow his expression) 'the vulgar notion of mental state' [or Stimmung, nastroenie]. For Tynyanov, the order and the character of the representations of meaning [predstavlenija značenija] depend not on mental state [Stimmung] but on the order and the character of speech activity [rečevaja dejatelnost'] (ibid., 105).

Tynyanov's understanding allows the Formalist redefinition of emotion in terms of the 'verbal gesture' or of the 'sound metaphor' (see Tynyanov's famous example of the 'verbal gesture' from Alexander Pushkin's poem A Fairytale about King Saltan). ${ }^{7}$ This is the way a new semantic unity emerges in Formalist semantics, a unity called the 'verbal gesture'. It has for its effect a strong deformation or moving potential of lexical semantics under the effect provoked by the rhythmic cohesion of the poetic line. ${ }^{8}$

\section{CONCLUSION}

This comparative analysis of the notion of 'emotion' [Gefüh/] within the German-speaking and Russian Formalist movements shows that both of these traditions replace the concept of 'simple emotion'-also understood as a 'spontaneous' and 'natural' one-with the new concept of 'composed', or purely 'relational', emotion, conceived as a kind of 'mental syntax'. This new vision of 'emotion' as a specific rhetorical organisation replaces the traditional psychological notion of the 'mental state', or 'mental disposition' [Stimmung]. Indeed, both formalisms treat emotion as a 'non-subjective', 'kinetic', 'syntactic' phenomenon ${ }^{9}$ located on the surface of aesthetic objects. Being dependent on the concepts of 'construction' and of 'sense of movement' [Bewegungsgefühl], this formalist 'emotion' is closely related to the psycholinguistic phenomenon of the so-called 'verbal gesture' [Sprachgebärde], as well as to the formalist notion of ostranenie.

\footnotetext{
7 [I v sumu ego pustuju/Sujut gramotu druguju]. And in his empty bag/They stuff another document.

Tynyanov interprets this accumulation of the 'hollow u' as a 'sound gesture', or a 'verbal gesture', seeking to create an impression of a real gesture aiming to fill an empty space (Tynyanov 2002 [1924], 128-129).

8 For more details, see: Tchougounnikov (2016b, 27-44).

9 On the kinaesthetic and more largely avant-gardist aspect of formalist approach, see: Sirotkina and Smith (2017).
} 


\section{REFERENCES}

Arens, K., 1989. Structures of Knowing: Psychologies of the Nineteenth Century Dordrecht-Boston-London: Kluwer Academic Publishers.

Aucouturier, M., 1994. Le Formalisme russe. Paris: PUF. Avenarius, R., 1907. Kritik der reinen Erfahrung, B. 1. Leipzig: O. R. Reisland

Avenarius, R., 1908. Kritik der reinen Erfahrung, B. 2. Leipzig: O. R. Reisland.

Avenarius, R., 2008 (1905). Kritika čistogo opyta. V populjarnom izloženii A. Lunačarskogo. Moskva: LKI/URSS.

Barasch, M., 1990. Modern Theories of Art: From impressionism to Kandinsky, Volume 2. New York: NYU Press.

Clausberg, K., 1983. Wiener Schule-Russischer Formalismus-Prager Strukturalismus. Ein komparatistisches Kapitel Kunstwissenschaft. In Hoffmann, W., Warnke, M. (Eds.), IDEA, Jahrbuch der Hamburger Kunsthalle, II, Kunst um 800. München: Prestel, pp. 151-180.

Clausberg, K., 2011. Wiener Schule im Rückblick. Einekurze Bildergeschichte aus Kunst-, Naturund Neurowissenschaft. In Bisanz E. (Ed.), Das Bild zwischen Kognition und Kreativität. Interdisziplinäre Zugänge zum bildhaften Denken. Bielefeld: Transcrpt Verlag, pp. 21-76.

Eisler, R., 1922. Handwörterbuch der Philosophie, (Zweite Auflage, neuherausgegeben von Richard Müller-Freienfels), B. 1. Berlin: Mittler und Sohn.

Erlich, V., 1951. Russian Formalism: Sources, History, Heritage, New York: Columbia University.

Hansen-Löve, A., 1978. Der russische Formalismus. Methodologische Rekonstruktion seiner Entwicklung aus dem Prinzip der Verfremdung. Wien: Verlag der österreichischen Akademie der Wissenschaften.

Hanslick, E., 1982 (1854). Vom Musikalisch-Schönen. Ein Beitrag zur Revision der Ästhetik der Tonkunst. Leipzig: Reklam.

Hildebrand, von A., 1913 (1893). Das Problem der Form in derbildenden Kunst. Strassburg: J. H. Heitz

Lipps, T., 1901. Das Selbstbewusstsein. Empfindung und Gefühl. Wiesbaden: Verlag von J. F. Bergmann.

Mach, E., 1886. Beiträge zur Analyse der Empfindungen. Jena: Verlag von Gustav Fischer.

Mach, E., 1897. Contributions to the analysis of the sensations. Chicago: The Open Court Publishing Company.

Maigné, C., 2009a. Formal'naja estetika Gerbarta i eë otraženie v russkom formalizme. In Dmitrieva, E., Zemskij V., Espagne, M., Le contexte européen du formalisme russe (croisements esthétiques: France, Allemagne, Italie, Russie). Actes du colloque franco-russe du 1-2 novembre 2005. Moskva: IMLI RAN, pp. 55-76.

Maigné, C., Trautmann-Waller, C. (Eds.) 2009. Formalismes esthétiques et héritage herbartien: Vienne, Prague, Moscou. Hildesheim, Zürich, New York: Olms Verlag.

Maigné, C. (Ed.), 2013. Formalisme eshtétique. Prague et Vienne au XIXe siècle. Textes réunis par Carole Maigné. Paris: Vrin.
Petzoldt, J., 1900. Einführung in die Philosophie der reinen Erfahrung, I. Bd. Die Bestimmtheit der Seele. Leipzig: B. G. Teubner.

Petzoldt, J., 1908. Einführung in die Philosophie der reinen Erfahrung, 2. Bd. Auf dem Wege zum Dauernden. Leipzig: B. G. Teubner.

Richter, D. H., 1998. The Critical Tradition. New York: Bedford/St. Martin's.

Riegl, A., 2008 (1902). Le portrait de groupe hollandais. Paris: Hazan.

Riegl, A., 2014 (1901). L'Industrie d'art romaine tardive. Paris: Macula.

Romand D., Tchougounnikov S. (Eds.), 2009. RHSH (Revue d'histoire des sciences humaines) N²1. Psychologie allemande et sciences humaines en Russie. Anatomie d'un transfert culturel (1860-1930). Paris: Sciences humaines Editions.

Romand, D., Tchougounnikov, S., 2008. Quelques sources psychologiques allemandes du formalisme russe: le cas des théories de la conscience. In Langage et pensée: Union soviétique années 1920-1930, Cahiers de I'ILSL, 24, 223-236.

Romand, D., Tchougounnikov, S., 2010. Le formalisme russe, une séduction cognitiviste. In Berelowitch, W., Espagne M. (Eds.), Cahiers du Monde russe, $N^{\circ}$ 51/4, Sciences humaines et sociales en Russie à l'Âge d'argent: quelques figures de transferts, pp. 521-546.

Romand, D., Tchougounnikov, S., 2013. Polivanov, psycholinguiste. Psychologie et formalisme en Russie dans les années 1910-1930, In Archaimbault S., Tchougounnikov S. (eds.), Evgenij Polivanov (18911938). Penser le langage aux temps de Staline. Paris, Institut d'études slaves, pp. 83-121.

Sirotkina, I., Smith, R., 2017. The Sixth Sense of the Avant-Garde. Dance, Kinaesthesia and the Arts in Revolutionary Russia. London, New-York: Bloomsbury Publishing.

Steila, D., 2013. Nauka i revoljucija. Recepcija empiriokriticizma v russkoj kul'ture (1877-1910). Moskva: Akademicheskij proekt.

Svetlikova, I., 2005. Istoki russkogo formalizma. Tradicija psixologizma i formalnaja škola. Moskva: Novoje literaturnoje obozrenije.

Tchougounnikov, S., 2014. Un chaînon manquant de la pensée formaliste. In Maigné, C. (ed.) 2012. Formalisme esthétique: Prague et Vienne au XIXe siècle. In Revue des Etudes Slaves, 85(1), 141-147.

Tchougounnikov, S., 2016. De la visibilité à la littérarité: l'atelier des formalismes européens. Revue des Etudes Slaves, 86, 353-357.

Tchougounnikov, S., 2016a. L'espace comme procédé: formalisme russe vs formalisme germanique. In Simonato, E., Moret, S., Cinquante nuances du temps et de l'espace dans les théories linguistiques. Cahiers de l'ILSL, $N^{\circ}$ 49. Lausanne: Université de Lausanne, pp. 27-51.

Tchougounnikov, S., 2016b. Le sentiment comme facteur sémantique: la sémantique représentationnelle entre la linguistique psychologique et le formalisme. Langage Design. Journal of Theoretical and Experimental 
European Formalism and Empiriocriticism: Formalism within the International Empiriocritical Movement

Linguistics, Special issue (2016), pp. 27-44, available at: <http://elies.rediris.es/Language_Design/ LD-SI-2016/indice_SI2016.html>.

Tchougounnikov, S., 2017. Prolegomeny k sravnitel'nomu analizu russkogo i nemeckojazyčnogo formaliszmov. In Levčenko, J., Pilščikov, I., Epoxa ostranenija. Russkij formalizm i sovremennoje gumantarnoe znanie. Moskva: Novoe literaturnoe obozrenie, pp. 103-114.

Tynianov, I., 2002 (1924). Literaturnaja evoljucija. Izbrannye trudy. Moskva: Agraf.

Walzel, O., 1923. Gehalt und Gestalt im Kunstwerk des Dichters. Berlin: Akademische Verlagsgesellschaft Athenaion.
Wiesing, L., 1997. Die Sichtbarkeit des Bildes. Geschichte und Perspektiven der formalen Ästhetik. Reinbek: Rowohlt. Wiesing, L., 2014 (1997). La visibilié de l'image. Histoire et perspectives de l'esthétique formelle (traduction par C. Maigné). Paris: Vrin.

Wölfflin, H., 1983 (1915). Kunstgeschichtliche Grundbegriffe. Das Problem der Stilentwicklung in der neuren Kunst. Dresden: VEB Verlag der Kunst.

Worringer, W., 1981 (1907). Abstraktion und Einfühlung. Ein Beitrag zur Stilpsychologie. Leipzig, Weimar: Kiepenheuer.

Return to front page $\uparrow$ 